\section{(2) \\ BRAZIILIAN JOURNAL \\ OF MEDICAL AND BIOLOGICAL RESEARCH}

www.bjournal.com.br
ISSN 0100-879X

Volume 45 (3) 179-290 March 2012

BIOMIEDICAL SCIENCES

AND

CLINICAL INVESTIGATION

Braz J Med Biol Res, March 2012, Volume 45(3) 187-196

doi: doi.10.1590/S0100-879X2012007500017

Tetramethylpyrazine potentiates arsenic trioxide activity against HL-60 cell lines

Yuni Wu, Youhua Xu, Yali Shen, Cuicui Wang, Gaili Guo and Tiantian Hu

The Brazilian Journal of Medical and Biological Research is partially financed by

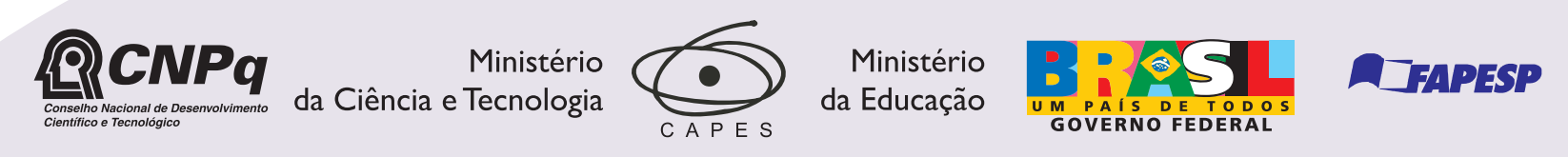

Institutional Sponsors

surpos
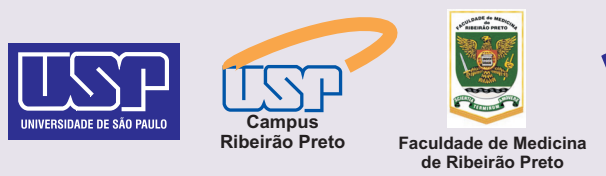

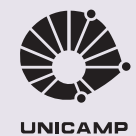

UNICAMP $\oplus$ SHIMADZU

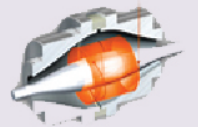

1D. Associaçäo Explore High - Performance MS Orbitrap Technology In Proteomics \& Metabolomics analitica $\underset{\text { analiticaweb.com.br }}{\text { Thermo }}$ S I ENTIFIC 


\title{
Tetramethylpyrazine potentiates arsenic trioxide activity against HL-60 cell lines
}

\author{
Yuni Wu1,2,3, Youhua $X u^{1,2,3}$, Yali Shen ${ }^{1,2,3}$, Cuicui Wang ${ }^{1,2,3}$, Gaili Guo ${ }^{1,2,3}$ \\ and Tiantian $\mathrm{Hu}^{1,2,3}$ \\ ${ }^{1}$ Key Laboratory of Developmental Diseases in Childhood, Chongqing, China \\ ${ }^{2}$ Key Laboratory of Pediatrics in Chongqing, Chongqing, China \\ ${ }^{3}$ Chongqing International Science and Technology Cooperation Center for Child Development and Disorders, \\ Chongqing, China
}

\begin{abstract}
The objective of this study was to evaluate the effects of tetramethylpyrazine (TMP) in combination with arsenic trioxide $\left(\mathrm{As}_{2} \mathrm{O}_{3}\right)$ on the proliferation and differentiation of $\mathrm{HL}-60$ cells. The $\mathrm{HL}-60$ cells were treated with $300 \mu \mathrm{g} / \mathrm{mL} \mathrm{TMP}, 0.5 \mu \mathrm{M} \mathrm{As} 2 \mathrm{O}_{3}$, and $300 \mu \mathrm{g} / \mathrm{mL}$ TMP combined with $0.5 \mu \mathrm{M} \mathrm{As}_{2} \mathrm{O}_{3}$, respectively. The proliferative inhibition rates were determined with MTT. Differentiation was detected by the nitroblue tetrazolium (NBT) reduction test, Wright's staining and the distribution of CD11b and CD14. Flow cytometry was used to analyze cell cycle distribution. RT-PCR and Western blot assays were employed to detect the expressions of c-myc, p27, CDK2, and cyclin E1. Combination treatment had synergistic effects on the proliferative inhibition rates. The rates were increased gradually after the combination treatment, much higher than those treated with the corresponding concentration of $\mathrm{As}_{2} \mathrm{O}_{3}$ alone. The cells exhibited characteristics of mature granulocytes and a higher NBT-reducing ability, being a 2.6-fold increase in the rate of NBT-positive ratio of HL-60 cells within the $\mathrm{As}_{2} \mathrm{O}_{3}$ treatment versus almost a 13-fold increase in the TMP $+\mathrm{As}_{2} \mathrm{O}_{3}$ group. Cells treated with both TMP and $\mathrm{As}_{2} \mathrm{O}_{3}$ expressed far more CD11b antigens, almost 2-fold compared with the control group. Small doses of TMP potentiate $\mathrm{As}_{2} \mathrm{O}_{3}$-induced differentiation of HL-60 cells, possibly by regulating the expression and activity of G0/G1 phase-arresting molecules. Combination treatment of $\mathrm{TMP}_{\mathrm{With}} \mathrm{As}_{2} \mathrm{O}_{3}$ has significant synergistic effects on the proliferative inhibition of HL-60 cells.
\end{abstract}

Key words: Tetramethylpyrazine; Acute promyelocytic leukemia; Arsenic trioxide; HL-60 cell; Proliferation; Differentiation

\section{Introduction}

A recent study revealed that differentiation may be associated with the induction of apoptosis, and thus, differentiation-inducing therapy may be useful in combination with intensive chemotherapy to increase the susceptibility of leukemia blast cells to drug-induced apoptosis (1). It has also been reported that hematopoietic tumors often arise as a consequence of uncontrolled proliferation of immature blasts that fail to terminally differentiate into mature blood cells; therefore, initiating a maturation program requires cell cycle arrest (2).

Arsenic trioxide $\left(\mathrm{As}_{2} \mathrm{O}_{3}\right)$ has been successfully used to treat acute promyelocytic leukemia (PML). In vitro studies have shown that micromolar concentrations of $\mathrm{As}_{2} \mathrm{O}_{3}$ can induce apoptosis of leukemia cells, while at lower concentrations (0.1-0.5 $\mu \mathrm{M}) \mathrm{As}_{2} \mathrm{O}_{3}$ induces cell differen- tiation $(3,4)$. These preclinical studies were confirmed by controlled clinical trials showing that treatment with $\mathrm{As}_{2} \mathrm{O}_{3}$ led to complete remission in acute PML patients (5). Because $\mathrm{As}_{2} \mathrm{O}_{3}$ at higher concentrations induces many side effects (ventricular arrhythmia, skin reaction, peripheral neuropathy, electrolyte changes, hepatic dysfunction, gastrointestinal reactions, etc.), low-dose combination therapy is required. In particular, combination treatment using two chemotherapeutic agents at low concentrations has been reported to have improved cytotoxic effects on cancer cells with minimal side effects.

Tetramethylpyrazine (TMP) is a compound extracted from the Chinese medicinal plant Ligusticum chuanxiong. The structure of the TMP is 2,3,5,6-tetramethylpyrazine and TMP is an amide alkaloid (6). The tubers of $L$. chuanxiong

Correspondence: Youhua Xu, Department of Hematology, Affiliated Children's Hospital, Chongqing Medical University, No. 136, Zhongshan 2nd Road, Yuzhong District, Chongqing 86 400014, China. E-mail: xuyouhua0504@163.com or 198371lc@163.com (Yuni Wu)

Received August 8, 2011. Accepted January 19, 2012. Available online February 17, 2012. Published March 19, 2012. 
have been used in traditional Chinese medicine for the treatment of cancer. TMP has been synthesized and widely used in oriental medicine to effectively treat several cardiovascular complications. Several studies have shown that TMP has various biological activities, such as antioxidant activity (7), the ability to modulate nitric oxide production (8), and cytotoxicity against various tumor cells (9). The hypotheses are clear. A previous study has found that TMP could promote apoptosis of the human promyelocytic leukemia cell line HL-60 in vitro (10); however, the effects of TMP in combination with $\mathrm{As}_{2} \mathrm{O}_{3}$ on the proliferation and differentiation of HL-60 cells are unknown, and the mechanisms by which this drug acts in the treatment of acute PML have not been established. Here, we report the effects of TMP alone and in combination with $\mathrm{As}_{2} \mathrm{O}_{3}$ on proliferation, cell cycle regulation, and differentiation of HL-60 cells.

\section{Material and Methods}

\section{Material}

HL-60 cells were bought from KeyGen Biotec Co. Ltd., China, and preserved in our laboratory. RPMI-1640, DMSO, 3-[4,5-dimethylthiazol-2-yl]-2,5-diphenyltetrazolium bromide (MTT), nitroblue tetrazolium (NBT), and 12-Otetradecanoylphorbol 13-acetate (TPA) were obtained from Sigma, USA. PCR primers were synthesized by Shanghai Sangon Biotechnology Co. Ltd., China. PEconjugated CD14 and FITC-conjugated CD11b antibodies were purchased from Beijing 4A Biotech Co. Ltd., China. Nuclear-cytosol extraction kit was purchased from KENGEN Biotechnology, China. Antibodies against p27KIP1, cyclin E1, cyclin-dependent kinase 2 (CDK2), and c-myc were obtained from Epitomics Co., USA. $\beta$-actin and goat antirabbit IgG-horseradish peroxidase (HRP) were obtained from Santa Cruz Biotechnology, USA. TMP was supplied by Shanghai Modern Hasen Pharmaceutical Co., Ltd., China. $\mathrm{As}_{2} \mathrm{O}_{3}$ was purchased from Beijing SL Pharmaceutical Co., Ltd., China.

\section{Cell culture}

HL-60 cells were maintained in RPMI-1640 medium supplemented with $100 \mathrm{U} / \mathrm{mL}$ penicillin, $100 \mu \mathrm{g} / \mathrm{mL}$ streptomycin, $1 \mathrm{mM} \mathrm{L-glutamine}$, and $10 \%$ heat-inactivated fetal bovine serum (FBS). The cells were grown in humidified atmosphere at $37^{\circ} \mathrm{C}$ in $5 \% \mathrm{CO}_{2}$. This study was approved by the Animal Ethics Committee of the Institute of Zoology at Chongqing Medical University.

\section{Cell counting and MTT assay}

To quantify the number of cells after each treatment, cells were counted at different incubation times using a hemocytometer under a light microscope. Cell viability was determined by the MTT assay (11). The blank wells were full of RPMI-1640 medium only, control wells contained untreated cells, and test cells were treated with the substance to be assayed.

Cell growth inhibition rate $(\%)=($ the absorbance $(A)$ at $590 \mathrm{~nm}$ of treated wells - the A590 value of blank wells) / (the A590 value of control wells - the A590 value of blank wells) $\times 100$.

\section{Wright's staining}

Cell morphology was examined using microscopy with Wright's staining. Briefly, cells were centrifuged onto glass slides, dried, stained, and examined at 1000X magnification using an Olympus light microscope (Olympus, Japan).

\section{Nitroblue tetrazolium reduction test}

The extent of differentiation was assessed by measurement of superoxide production, monitored by reduction of NBT (12). A total of 200 cells were counted under a light microscope, and the percent of cells containing membrane deposits of reduced blue-black formazan was recorded.

\section{Cell surface differentiation antigen expression assay}

Approximately $1 \times 10^{6}$ cells were collected from each experimental group and washed twice with ice-cold phosphate-buffered saline (PBS), $\mathrm{pH}$ 7.4. Expression of the cell surface antigens CD11b and CD14 was determined by cytofluorometric analysis. Briefly, $20 \mu \mathrm{L}$ of either FITCconjugated CD11b or PE-conjugated CD14 antibody was added to $100 \mu \mathrm{L}$ PBS and incubated at $4^{\circ} \mathrm{C}$ for $2 \mathrm{~h}$. The cells were then resuspended in PBS solution containing paraformaldehyde, after which cytofluorometric analysis was performed (BD FACS Calibur Co., USA) with a sample size of at least 10,000 cells. The expression of CD14 and $\mathrm{CD} 11 \mathrm{~b}$ is reported as cell percent. The gate excludes debris, outliers, and events that lie far away from the mean. Data were stored and processed using the FACScan software.

\section{Cell cycle analysis}

Approximately $0.5 \times 10^{6}$ cells were collected from cultures, washed twice with PBS, fixed in $70 \%$ ice-cold ethanol, and stored at $-20^{\circ} \mathrm{C}$ overnight. The fixed cells were then collected and resuspended in PBS containing $50 \mathrm{mg} /$ $\mathrm{mL} \mathrm{PI}$ and $100 \mu \mathrm{g} / \mathrm{mL}$ DNase-free RNase A. Cells were incubated for $1 \mathrm{~h}$ at room temperature and then analyzed by flow cytometry.

\section{Reverse transcription-polymerase chain reaction (RT-PCR) analysis of CDK2, cyclin E1, c-myc, and p27 KIP1}

At the indicated times, $1 \times 10^{7}$ cells of each experimental group were collected, and total cell RNA was isolated using Trizol reagent. RNA concentration was determined by UV absorption at $260 \mathrm{~nm}$. The RNA was reverse transcribed into cDNA, which then underwent PCR in a final volume of $25 \mu \mathrm{L}$ as follows: $95^{\circ} \mathrm{C}$ for $5 \mathrm{~min}, 30$ cycles at $95^{\circ} \mathrm{C}$ for 1 min, specific annealing temperature for $1 \mathrm{~min}, 72^{\circ} \mathrm{C}$ for 1 
Table 1. Primers and annealing temperatures.

\begin{tabular}{lllcc}
\hline Gene & \multicolumn{1}{c}{ Sense } & Antisense & Size (bp) & $\begin{array}{c}\text { Annealing } \\
\text { temperature }\end{array}$ \\
\hline c-myc & 5'-GATTCTCTGCTCTCCTCGAC-3' & 5'-TCCAGACTCTGACCTTTTGC-3' & 180 & $55^{\circ} \mathrm{C}$ \\
p27KIP1 & 5'-ATGTCACGTGCGAGTGTC-3' & 5'-TCTGTAGTAGAACTCGGGCAA-3' & 270 & $55^{\circ} \mathrm{C}$ \\
CDK2 & 5'-CCTTGTTTGTCCCTTCTAC-3' & 5'-CAAATCCACCCACTATGA-3' & 395 & $55^{\circ} \mathrm{C}$ \\
Cyclin E1 & 5'-CTGGATGTTGACTGCCTTGA-3' & 5'-CCGCTGCTCTGCTTCTTAC-3' & 359 & $52^{\circ} \mathrm{C}$ \\
B-actin & 5'-AAGATGACCCAGATCATGTTTGAGACC-3' & 5'-GCCAGGTCCAGACGCAGGAT-3' & 191 & $52^{\circ} \mathrm{C}$ \\
\hline
\end{tabular}

PCR primers were synthesized by Shanghai Sangon Biotechnology Co. Ltd., China.

min, and an additional extension at $72^{\circ} \mathrm{C}$ for 10 min. The primer sequences and annealing temperatures are shown in Table 1. The PCR products were detected by gel electrophoresis and ultraviolet transillumination.

\section{Western blotting}

$\mathrm{HL}-60$ cells were collected, washed twice with ice-cold PBS, and harvested in sodium dodecyl sulfate (SDS) lysis buffer (2\% SDS, 50 mM dithiothreitol, $62.5 \mathrm{mM}$ Tris- $\mathrm{HCl}, \mathrm{pH}$ 6.8). The protein sample concentration was quantified using the BCA method, and an equal amount of protein $(30 \mu \mathrm{g})$ was loaded onto each well of a $10 \%$ SDS polyacrylamide gel. Cell extracts were separated by polyacrylamide gel electrophoresis (PAGE) and transferred to a polyvinylidene difluoride membrane (PVDF). The primary antibodies used were anti$\beta$-actin (1:500), anti-p27 KIP1 (1:1000), anti-cyclin E1 (1:800), anti-CDK2 (1:1000), and anti-c-myc (1:800). HRP-conjugated anti-lgG was used as the secondary antibody.

\section{Statistical analysis}

Statistical analyses were performed using SPSS 17.0 Student Edition for Windows. Differences between groups were examined for statistical significance by analysis of variance (ANOVA). $P<0.05$ was considered to be statistically significant.

\section{Results}

TMP, alone or in combination with $\mathrm{As}_{2} \mathrm{O}_{3}$ has effects on proliferative inhibition

TMP has an anticancer effect on HL-60 cells with HL-60 cell viability being reduced in a concentration- and time-dependent manner (Figure 1A). However, this inhibitory effect became apparent as no more than $50 \%$ at a concentration of $300 \mu \mathrm{g} /$ $\mathrm{mL}$ TMP; therefore, this concentration was used throughout the study. Combined treatment with 300
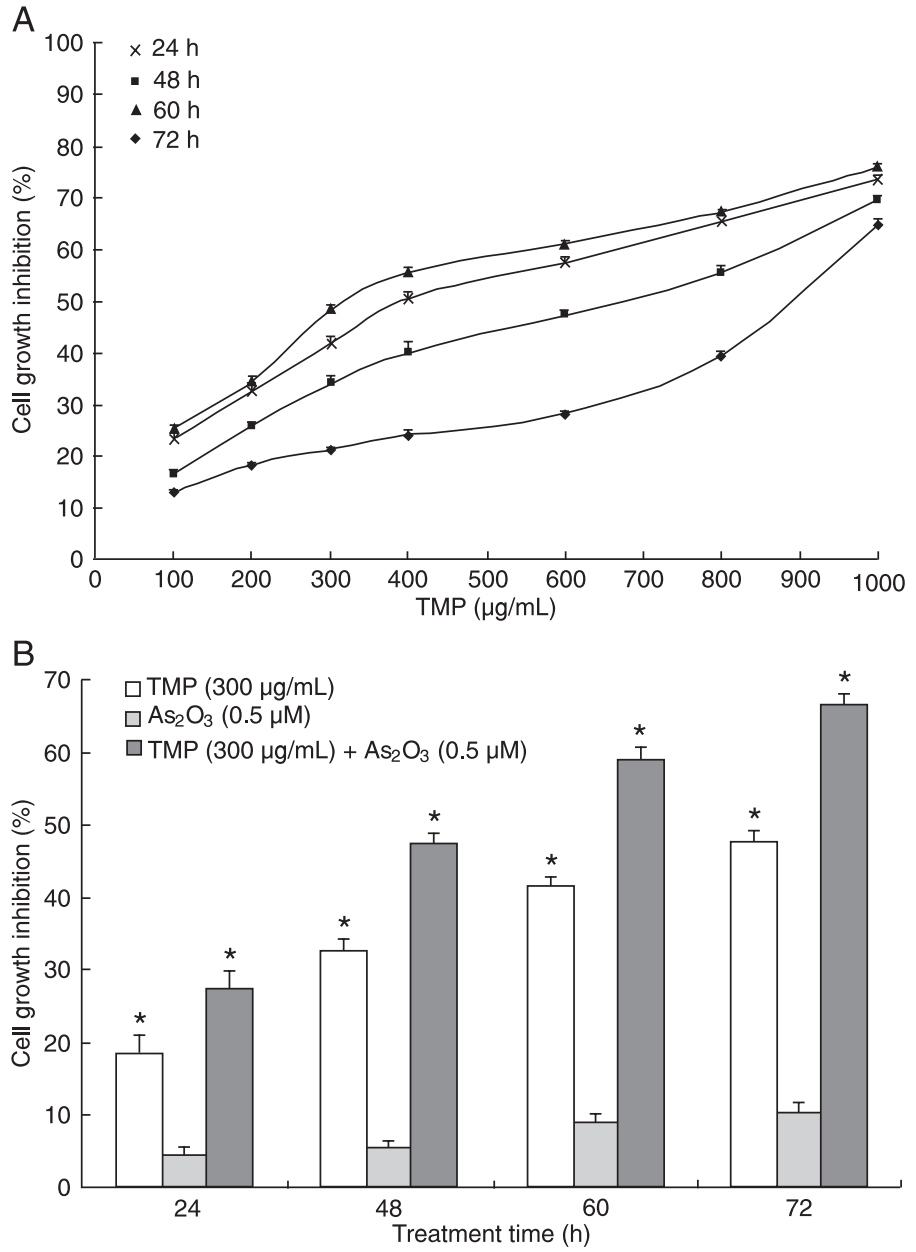

Figure 1. Effect of tetramethylpyrazine (TMP) and arsenic trioxide $\left(\mathrm{As}_{2} \mathrm{O}_{3}\right)$ on the rate of HL-60 cell growth inhibition. Growth inhibition was determined using the MTT assay. $A$, Cells were treated with various concentrations of TMP for the indicated times. The growth of HL-60 cells was significantly inhibited by TMP in a dose- and time-dependent manner. $B$, Cells were treated with $300 \mu \mathrm{g} / \mathrm{mL}$ TMP plus $0.5 \mu \mathrm{M} \mathrm{As}{ }_{2} \mathrm{O}_{3}$ for the indicated periods. The results are reported as means \pm SD for three independent experiments. ${ }^{*} \mathrm{P}<0.05$ compared to cells treated with $\mathrm{As}_{2} \mathrm{O}_{3}$ alone in every group (groups of 24,48 , and $72 \mathrm{~h}$; ANOVA). 
$\mu \mathrm{g} / \mathrm{mL} \mathrm{TMP}$ and $0.5 \mu \mathrm{M} \mathrm{As}{ }_{2} \mathrm{O}_{3}$ had a synergistic effect on inhibiting the proliferation of HL-60 cells. This synergistic effect occurred in a time-dependent manner (Figure 1B). Importantly, the proliferation was inhibited much more effectively with the combined treatment than with treatment with $\mathrm{As}_{2} \mathrm{O}_{3}$ alone $(\mathrm{P}<0.01)$.

\section{Effects of TMP and $\mathrm{As}_{2} \mathrm{O}_{3}$ on the morphology of HL-60 cells}

After incubation for 3 days, treated cells were selected and stained with Wright's solution (Figure 2A-D). HL-60 cells treated with the combination of TMP and $\mathrm{As}_{2} \mathrm{O}_{3}$ were characterized by a decreased nuclear/cytoplasmic ratio and irregular nuclear shape (kidney-shaped nuclei, nuclear lobulation, and broad bean nuclei). The morphologic changes in the combination group were more obvious than those observed in cells treated with $\mathrm{As}_{2} \mathrm{O}_{3}$ alone.

\section{Effects of TMP and $\mathrm{As}_{2} \mathrm{O}_{3}$ on NBT reduction ability in HL-60 cells}

Consistent with the morphologic change, the ability of $\mathrm{HL}-60$ cells to reduce NBT significantly increased following a 3-day combined treatment with TMP and $\mathrm{As}_{2} \mathrm{O}_{3}$ when compared to either a control group or a group treated with
$\mathrm{As}_{2} \mathrm{O}_{3}$ alone ( $\mathrm{P}<0.01$; Figure 3$)$. Compared to the control group, there was a 2.6-fold increase in NBT-positive cells in the $\mathrm{As}_{2} \mathrm{O}_{3}$ group versus a nearly 13 -fold increase in the TMP plus $\mathrm{As}_{2} \mathrm{O}_{3}$ group. Also, there was a significant difference in percent NBT-positive cells between samples treated with TMP and samples treated with $\mathrm{As}_{2} \mathrm{O}_{3}$ plus TMP. These data provide further evidence that TMP could have a stimulatory effect on $\mathrm{As}_{2} \mathrm{O}_{3}$-induced differentiation.

\section{TMP and $\mathrm{As}_{2} \mathrm{O}_{3}$ induce $\mathrm{G} 1$ cell cycle arrest}

Differentiation resulting from treatment has been shown to accompany decreased proliferation (13). Based on the observed increase in differentiation following TMP and $\mathrm{As}_{2} \mathrm{O}_{3}$ treatment, we examined cell cycle arrest following treatment in HL-60 cells. Cells cultured with TMP exhibited a significant decrease in percent arrest in the S phase. There was also an increase in percent cells in G0/G1 following TMP treatment, from $39.1 \%$ in the control group to $53.7 \%$ after TMP treatment $(P<0.001$; Figure 4). There was no cell cycle arrest following $\mathrm{As}_{2} \mathrm{O}_{3}$ treatment alone (Figure 4). However, the combined treatment decreased the percentage of cells in the $S$ phase and increased the percentage of cells in the G0/G1 phase when compared to both the control group and the $\mathrm{As}_{2} \mathrm{O}_{3}$-treated group $(\mathrm{P}<0.001)$.
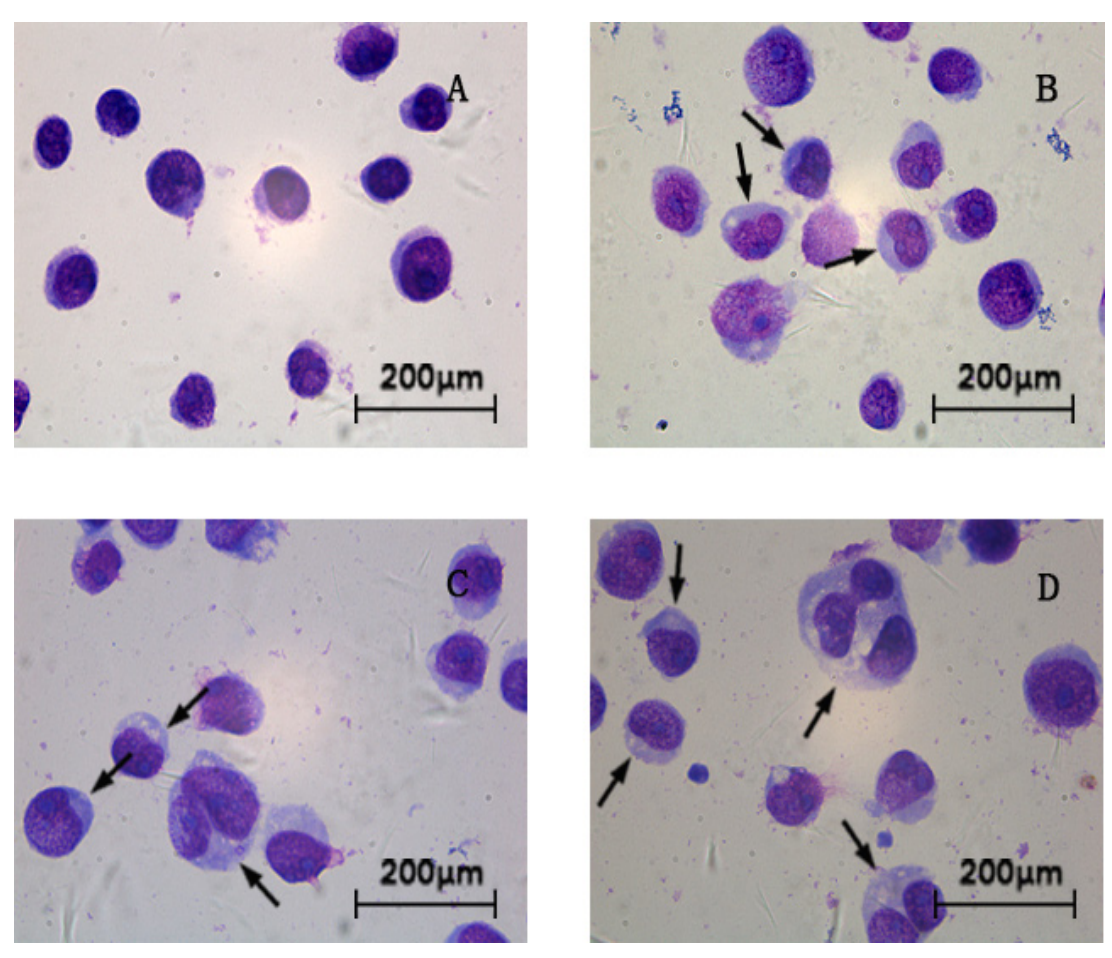

Figure 2. Effects of tetramethylpyrazine (TMP) and arsenic trioxide $\left(\mathrm{As}_{2} \mathrm{O}_{3}\right)$ on the morphology of $\mathrm{HL}-60$ cells. Cells were treated with $A$, control (untreated); $B, 300 \mu \mathrm{g} / \mathrm{mL}$ TMP; $C, 0.5 \mu \mathrm{M} \mathrm{As}_{2} \mathrm{O}_{3}$, and $D, 300 \mu \mathrm{g} / \mathrm{mL} \mathrm{TMP}+0.5 \mu \mathrm{M} \mathrm{As}{ }_{2} \mathrm{O}_{3}$, and then stained with Wright's solution and examined at a $1000 \mathrm{X}$ magnification using a light microscope. The experiments were repeated three times. Cells (arrows) were characterized by decreased nuclear/cytoplasmic ratio and irregular nuclear shape.

\section{Flow cytometry analysis of cell-surface differentiation and antigen expression}

$\mathrm{HL}-60$ differentiation yields both monocytic and granulocytic cells; thus, cell differentiation was analyzed after incubating the cells with TMP alone or in combination with $\mathrm{As}_{2} \mathrm{O}_{3}$ for $72 \mathrm{~h}$. CD14 is expressed exclusively when cells differentiate into monocytes, while CD11b is a monocyte- and granulocyte-specific marker. When compared to the control group, combined treatment with TMP plus $\mathrm{As}_{2} \mathrm{O}_{3}$ increased the expression of CD11b nearly 2-fold $(P<0.05$; Figure 5). Both CD11b and CD14 expression differed significantly between samples treated with $\mathrm{As}_{2} \mathrm{O}_{3}$ plus TMP and control samples (Table 2), indicating that HL-60 cells differentiated through both the granulocytic and monocytic pathway following combined treatment with TMP plus $\mathrm{As}_{2} \mathrm{O}_{3}$.

\section{Effects of TMP and $\mathrm{As}_{2} \mathrm{O}_{3}$ on the expressions of cell cycle regulatory proteins}

To determine the possible mecha- 
nism by which TMP causes cell cycle arrest, we analyzed cell cycle-related protein expression using Western blotting. The results revealed that combined treatment with $\mathrm{As}_{2} \mathrm{O}_{3}$ and TMP resulted in a reduction in the levels of cyclin $\mathrm{E} 1$ and CDK2 (Figure 6B), while the levels of the related CDK

A
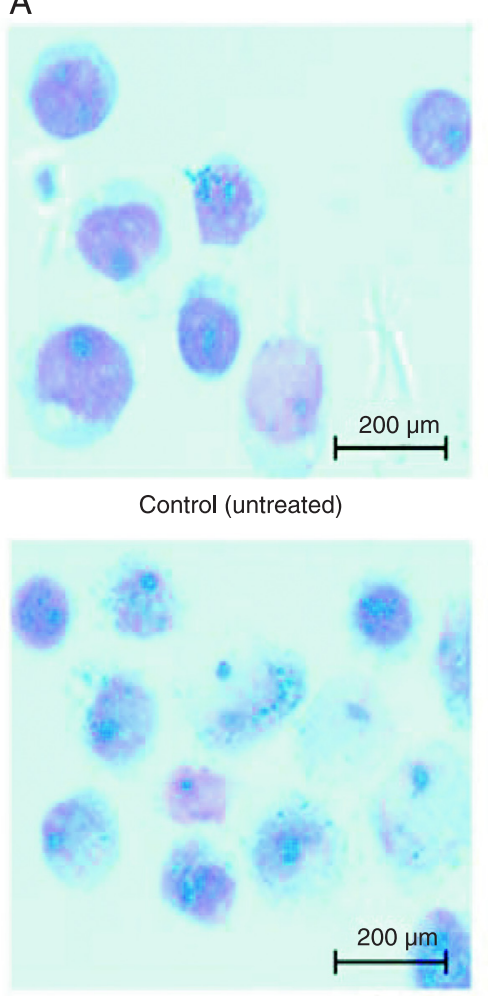

B

$$
\mathrm{As}_{2} \mathrm{O}_{3}(0.5 \mu \mathrm{M})
$$

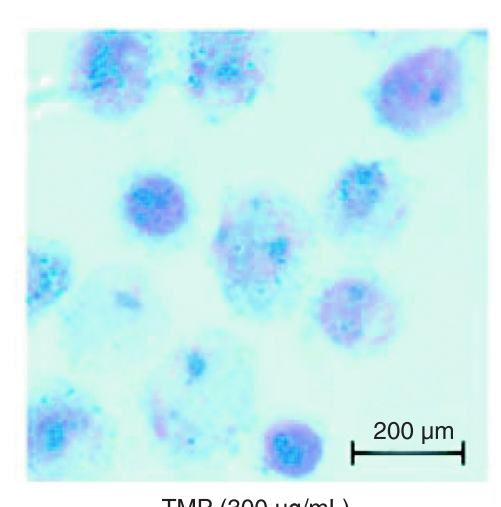

$\operatorname{TMP}(300 \mu \mathrm{g} / \mathrm{mL})$

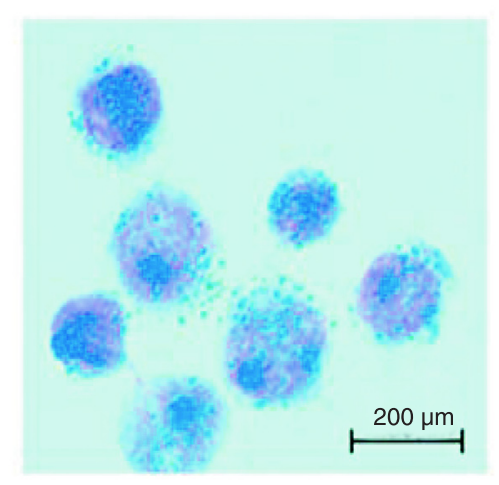

$\operatorname{TMP}(300 \mu \mathrm{g} / \mathrm{mL})+\mathrm{As}_{2} \mathrm{O}_{3}(0.5 \mu \mathrm{M})$

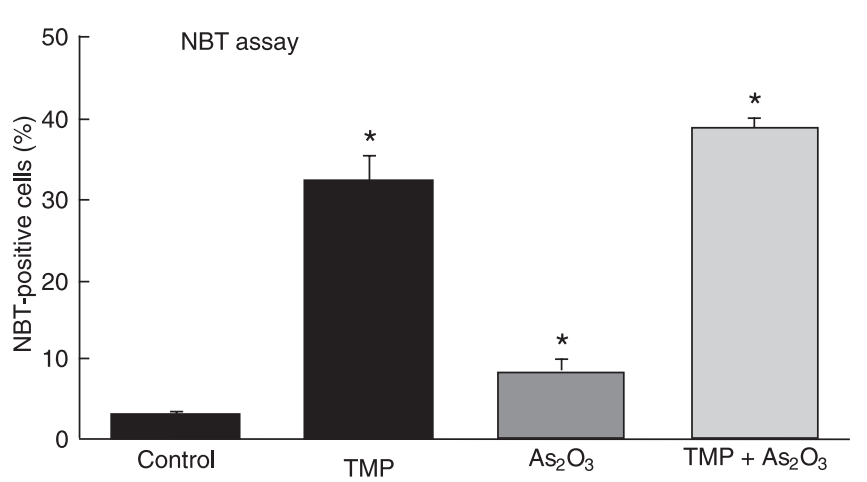

Figure 3. Effects of tetramethylpyrazine (TMP) and arsenic trioxide $\left(\mathrm{As}_{2} \mathrm{O}_{3}\right)$ on the nitroblue tetrazolium (NBT) reduction ability of HL-60 cells. HL-60 cells were untreated (control) or treated with TMP, $\mathrm{As}_{2} \mathrm{O}_{3}$, or TMP combined with $\mathrm{As}_{2} \mathrm{O}_{3}$. A, Cells containing membrane deposits of reduced blue-black formazan were counted and examined at $1000 \mathrm{X}$ magnification. $B$, We found that the NBT reduction ability of HL-60 cells incubated with TMP combined with $\mathrm{As}_{2} \mathrm{O}_{3}$ for 3 days was significantly increased when compared with either the control group or the $\mathrm{As}_{2} \mathrm{O}_{3}$-alone group. All assays were performed in triplicate. ${ }^{*} \mathrm{P}<0.05$ compared to control (ANOVA). inhibitor p27KIP1 increased after the combined treatment. Based on the observed protein levels, mRNA levels of were also found to be increased; however, the expression of CDK2 and cyclin E1 mRNA did not change (Figure 6A). The c-myc protein is a member of the region/ helix-loop-helix/leucine zipper (bHLHZip) transcription factor family, which is implicated in regulation of proliferation and differentiation in multiple cell types. In agreement with the RT-PCR results, there was also decreased c-myc protein expression in response to combined treatment with TMP plus $\mathrm{As}_{2} \mathrm{O}_{3}$ (Figure $6 \mathrm{~A}, \mathrm{~B})$. These results provide new insight into c-myc function in the regulation of the fate of HL-60 cells.

\section{Discussion}

TMP is widely used in the treatment of ischemic stroke and has been reported to possess a diverse array of pharmacological functions, such as modulation of arterial resistance, cerebral blood flow, platelet function, microcirculation, and capillary permeability (14-16). TMP has been in clinical use for decades at doses ranging from 40 to $2000 \mathrm{mg}$ in adults. Few adverse reactions to TMP have been reported, supporting the safety of treatment with this agent.

The present study demonstrates that TMP inhibits HL-60 cell proliferation in a dose- and time-dependent manner. Moreover, we found that TMP exerts a stimulatory effect on $\mathrm{As}_{2} \mathrm{O}_{3}$-induced $\mathrm{HL}$ 60 cell cycle arrest and that this arrest leads to the inhibition of cell proliferation and the induction of differentiation. This observation prompted us to investigate the effects of TMP and $\mathrm{As}_{2} \mathrm{O}_{3}$ on cell cycle regulation and the characteristics of HL-60 differentiation.

The induction of differentiation and cell cycle arrest are often used to assess the efficacy of novel anti-tumor compounds. Blockade of the cell cycle is regarded as an effective strategy for eliminating cancer cells (17). Our study indicates that the inhibitory effect of combined TMP and $\mathrm{As}_{2} \mathrm{O}_{3}$ treatment on cell proliferation is a result of induction of G1 phase arrest. The induction of differentiation in malignant cells can have positive clinical implications, such as loss of proliferative potential and induction 
of apoptosis (18). To further investigate the mechanism by which TMP exerts its stimulatory effect on $\mathrm{As}_{2} \mathrm{O}_{3}$-induced differentiation, we investigated the effect of the expression of several cell cycle regulatory proteins. The results provided convincing evidence that TMP in combination with $\mathrm{As}_{2} \mathrm{O}_{3}$ exerts its effects on cell cycle progression mainly via up- regulation of $\mathrm{p} 27^{\mathrm{KIP} 1}$ protein and mRNA expression. The cell cycle is regulated by a complex machinery, in which CDKs, CKIs, and cyclins play essential roles (19). CKIs, including $\mathrm{p} 27_{\mathrm{KIP} 1}$, are tumor suppressor proteins that downregulate cell cycle progression by binding to active CDKcyclin complexes, thereby inhibiting their kinase activities

A
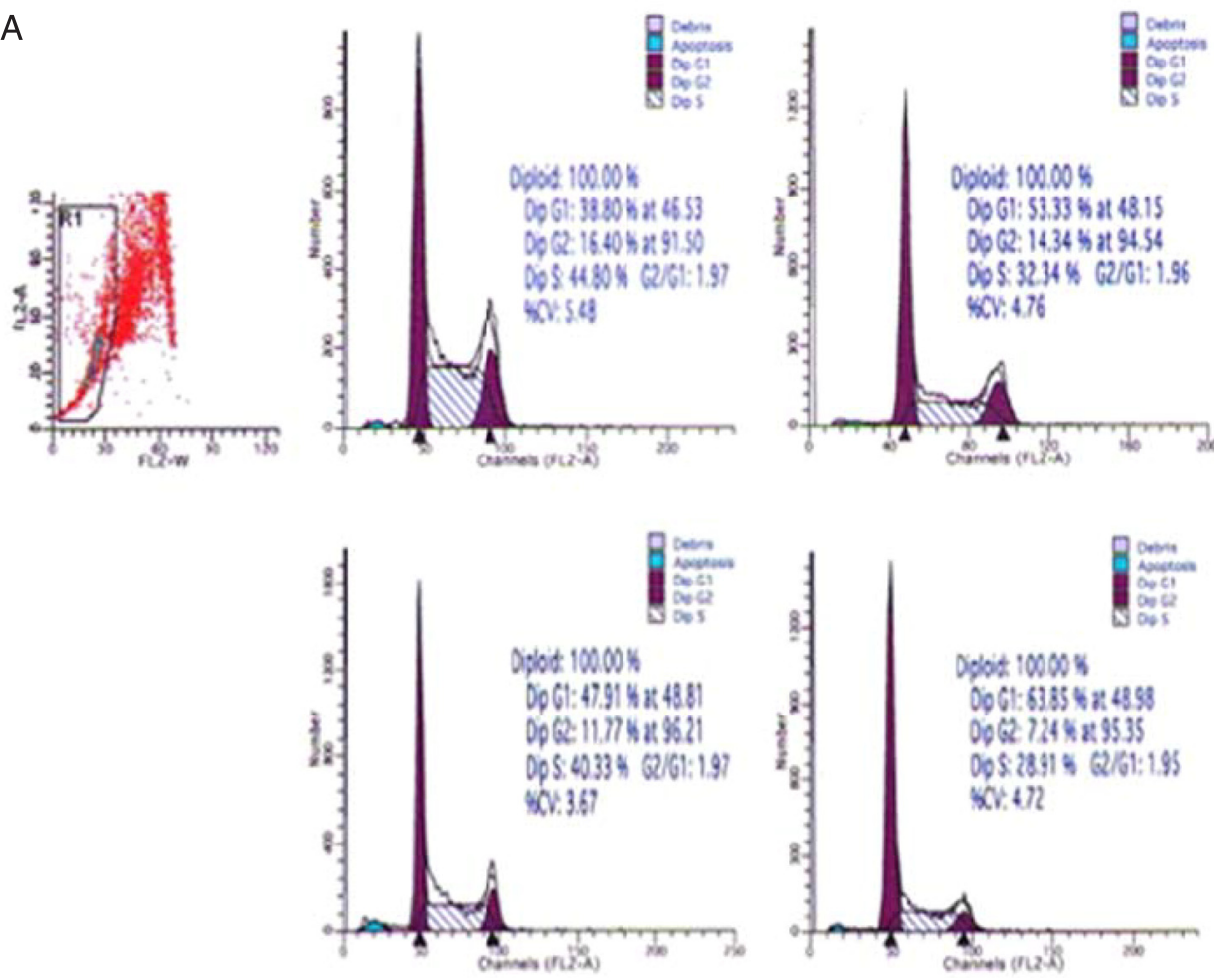

B

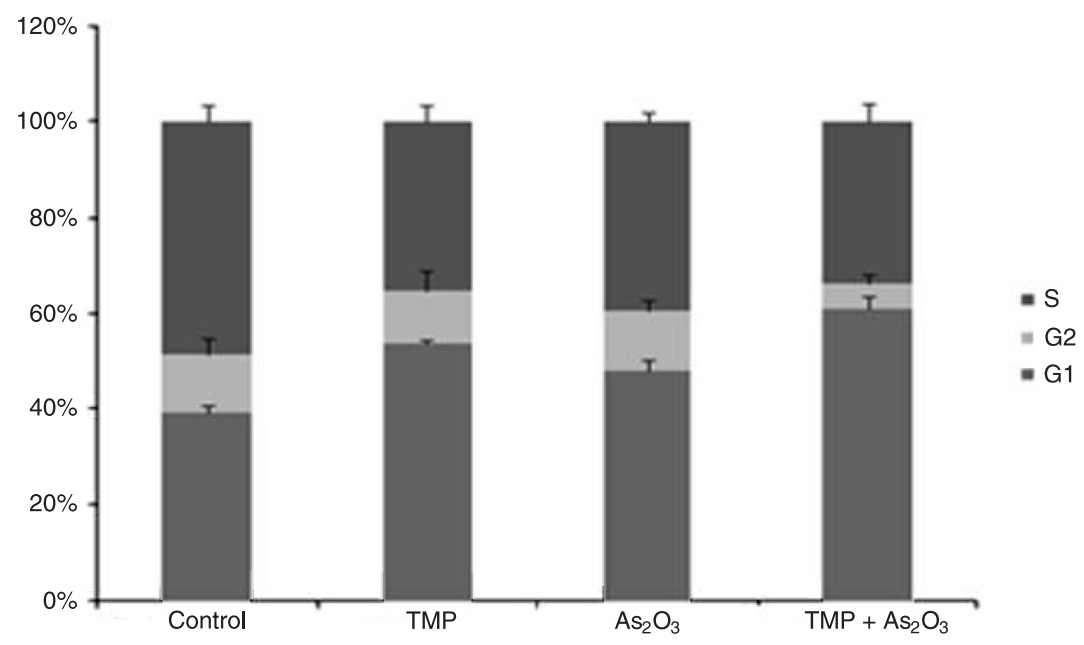

Figure 4. Tetramethylpyrazine (TMP) and arsenic trioxide $\left(\mathrm{As}_{2} \mathrm{O}_{3}\right)$ induce $\mathrm{G} 1$ cell cycle arrest in $\mathrm{HL}-60$ cells. $A$, Cells were treated with TMP, $\mathrm{As}_{2} \mathrm{O}_{3}$, or TMP combined with $\mathrm{As}_{2} \mathrm{O}_{3}$ for the indicated duration before analysis by flow cytometry. $B$, We found that combined treatment decreased the percent of cells in the S phase and increased the percent of cells in the G0/G1 phase. The results are reported as means \pm SD for three independent experiments. 
$(20,21)$. When we compared cell cycle phase distribution with alternations in cell cycle regulatory molecules, it was apparent that CKI up-regulation is one of the major causes of combination chemotherapy-induced G1 arrest and cell
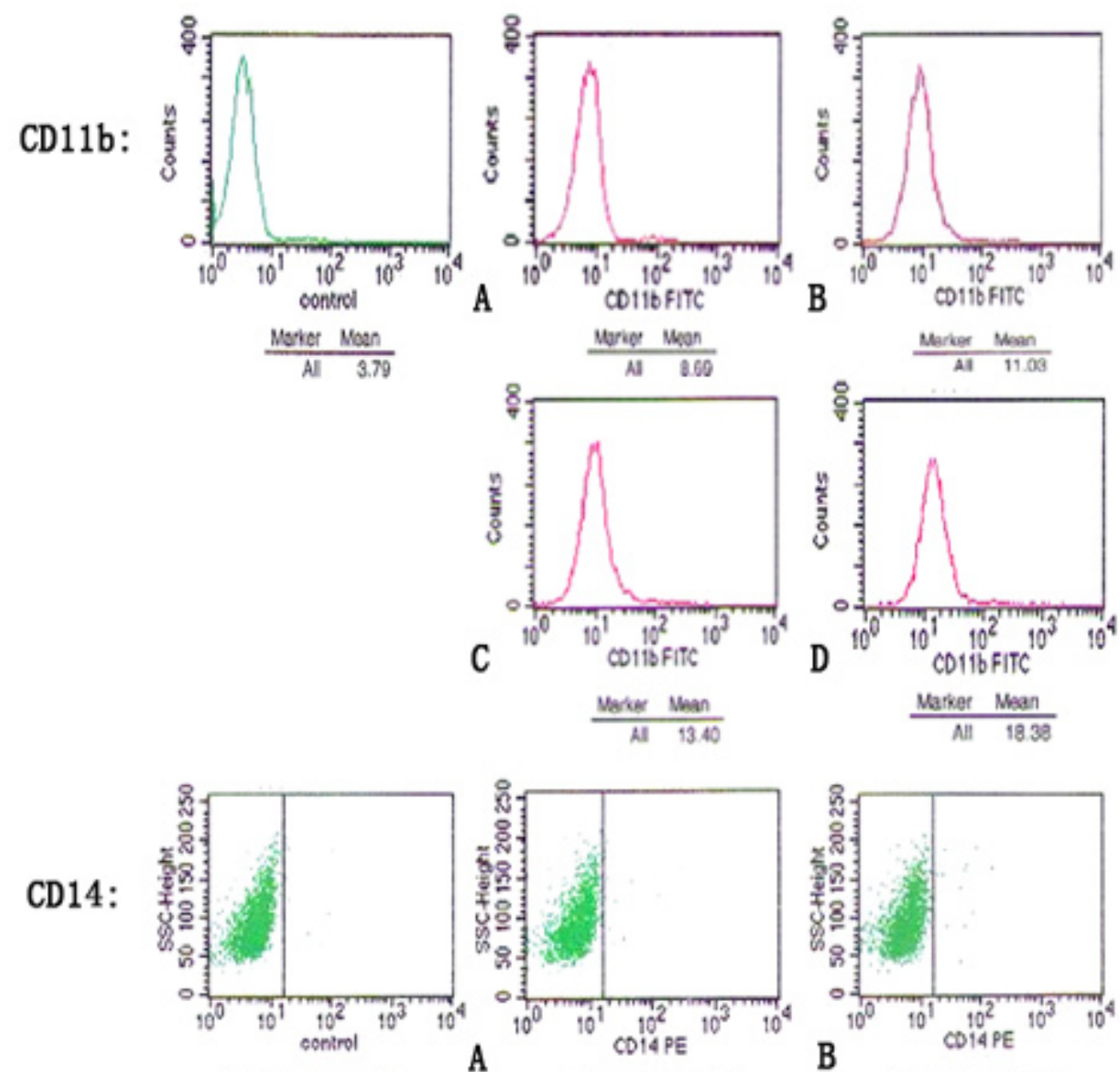

Quad Location: 16, 0

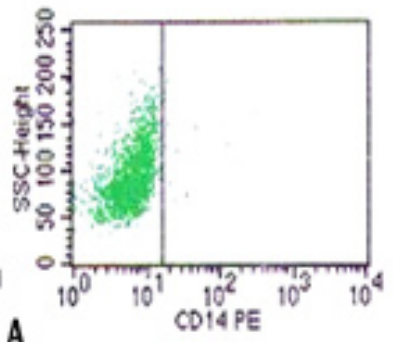

A

Ousd Localion. 16, 0
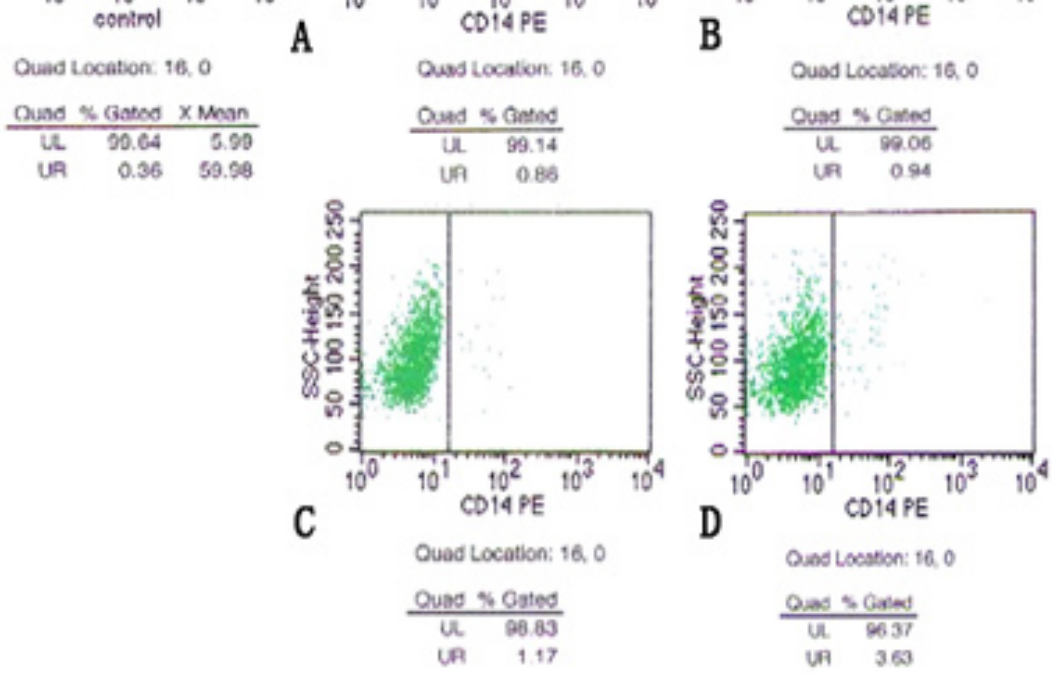

Figure 5. Expression of the CD11b granulocytic mature cell surface marker and CD14 monocyte surface marker determined with fluorescent-labeled antibodies. Cells were cultured without treatment ( $A$, control); $B, 300 \mu \mathrm{g} / \mathrm{mL} \mathrm{TMP} ; C, 0.5 \mu \mathrm{M} \mathrm{As} \mathrm{O}_{3}$, and $D, 300 \mu \mathrm{g} /$ $\mathrm{mL}$ TMP $+0.5 \mu \mathrm{M} \mathrm{As}_{2} \mathrm{O}_{3}$ for $72 \mathrm{~h}$. 
growth inhibition. Among the CDKs that regulate the cell cycle, CDK2 is known to be activated in association with cyclin E1 during G1 progression and G1-S transition. Our study reveals that, although the mRNA expression of CDK2 and cyclin E1 did not change, there was a marked reduction in the protein levels of cyclin E1 and CDK2 after the combined treatment. This suggests that the p $27^{\mathrm{KIP} 1}$ protein is binding to active cyclin E1 and CDK2, inhibiting their kinase activities.

C-myc promotes both apoptosis and differentiation in a transcriptional activity-dependent manner. The repression of c-myc has been demonstrated to be required for terminal differentiation of many cell types, including myeloid cells, and deregulated c-myc has been found to induce growth arrest (22). Inhibition of c-myc/Max dimerization affects multiple cellular activities in acute myeloid leukemia cells and represents a potential antileukemic approach (23). Here, we establish that c-myc expression affects the differentiation pattern in PML-RARa-negative HL-60 cells when induced by TMP, alone or in combination with $\mathrm{As}_{2} \mathrm{O}_{3}$. The results show that c-myc down-regulation is concomitant with down-regulation of cyclin E1 and up-regulation of $\mathrm{p} 27^{\mathrm{KIP} 1}$, as expected from previous reports (24). To further investigate the mechanism by which $0.5 \mu \mathrm{M} \mathrm{As}{ }_{2} \mathrm{O}_{3}$ can induce $\mathrm{HL}-60$ cells to undergo partial differentiation without a statistically significant cell cycle arrest, it is important to observe the c-myc expression changes. Since c-myc protein expression decreased persistently, while cyclin E1 and

Table 2. Expression of CD11b and CD14 in HL-60 cells.

\begin{tabular}{lcc}
\hline Drug concentration & Percent of CD11b expression & Percent of CD14 expression \\
\hline Control group & $2.246 \pm 0.092$ & $0.503 \pm 0.065$ \\
TMP $(300 \mu \mathrm{g} / \mathrm{mL})$ & $3.123 \pm 0.110^{*}$ & $0.587 \pm 0.070$ \\
$\mathrm{As}_{2} \mathrm{O}_{3}(0.5 \mu \mathrm{M})$ & $3.493 \pm 0.139^{*}$ & $0.857 \pm 0.042$ \\
$\mathrm{TMP}\left(300 \mu \mathrm{g} / \mathrm{mL}+\mathrm{As}_{2} \mathrm{O}_{3} 0.5 \mu \mathrm{M}\right)$ & $4.833 \pm 0.166^{*}$ & $1.986 \pm 0.387$ \\
\hline
\end{tabular}

The percentages of $\mathrm{CD} 11 \mathrm{~b}$ and $\mathrm{CD} 14$ expression are reported as means \pm SD for three independent experiments. TMP $=$ tetramethylpyrazine; $\mathrm{As}_{2} \mathrm{O}_{3}=$ arsenic trioxide. ${ }^{*} \mathrm{P}<0.01$ compared to control cells (ANOVA).

A

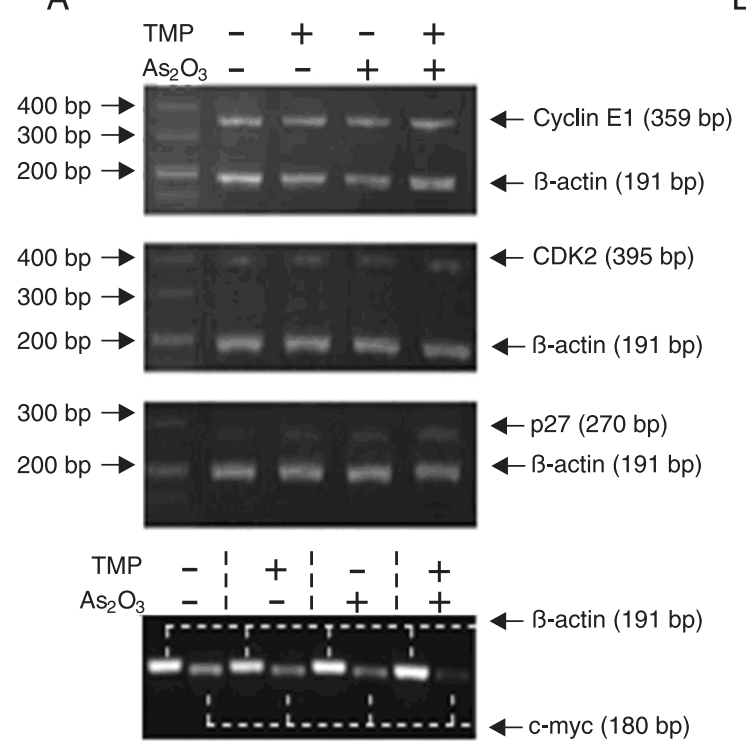

B

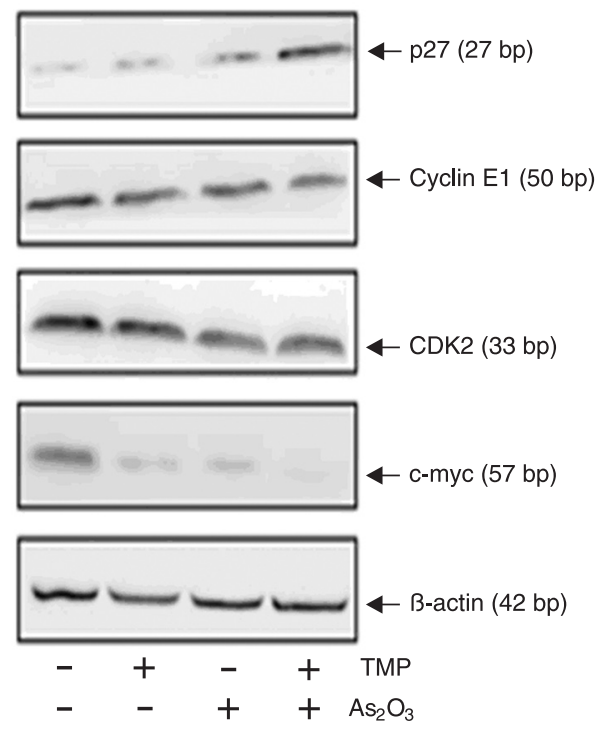

Figure 6. $A$, Expression of p27, c-myc, CDK2, and cyclin E1 mRNA determined by RT-PCR. Cells were cultured without treatment or treated with tetramethylpyrazine (TMP), arsenic trioxide $\left(\mathrm{As}_{2} \mathrm{O}_{3}\right)$, or TMP combined with $\mathrm{As}_{2} \mathrm{O}_{3}$ for $72 \mathrm{~h}$. B, Expression of p27, c-myc, CDK2, and cyclin E1 protein was determined using Western blotting. 
CDK protein levels were slightly affected, we speculate that c-myc may be responsible for the partially blocked differentiation observed. The presence of decreased c-myc expression throughout the analysis confirms previous findings obtained with PML cells (25). The increase in p27KIP1 expression at this $\mathrm{As}_{2} \mathrm{O}_{3}$ concentration suggests that cells are preparing to induce cell cycle arrest. From these results, we suggest a model whereby TMP plus $\mathrm{As}_{2} \mathrm{O}_{3}$-induced $\mathrm{GO}$ / $\mathrm{G} 1$ arrest during terminal $\mathrm{HL}-60$ cell differentiation is associated with up-regulation of p27, down-regulation of c-myc, and a slight down-regulation of CDK2 and cyclin E1.

Both efficacy and side effects need to be considered when evaluating a drug. $\mathrm{As}_{2} \mathrm{O}_{3}$ is a well-known chemical compound that, despite its high toxicity, has been used since the fifteenth century (26). Because $\mathrm{As}_{2} \mathrm{O}_{3}$ at higher concentrations induces many side effects and chronic arsenic exposure is linked to carcinogenesis, low-dose combination therapy is required $(27,28)$. Together with increasing doses, $\mathrm{As}_{2} \mathrm{O}_{3}$ caused an increase in the number of cells undergoing apoptosis (29). In our study, a low-dose combination of two chemotherapeutic agents $(300 \mu \mathrm{g} / \mathrm{mL}$ TMP plus 0.5 $\mu \mathrm{M} \mathrm{As}{ }_{2} \mathrm{O}_{3}$ ) markedly decreased cell viability and induced differentiation throughout the cell cycle, as detected by a slower rate of accumulation in G0/G1. In summary, our results indicate that $\mathrm{As}_{2} \mathrm{O}_{3}$ in combination with TMP is of potential chemotherapeutic use in PML-RARa-negative leukemia.

\section{References}

1. Bruserud O, Gjertsen BT, Huang T. Induction of differentiation and apoptosis - a possible strategy in the treatment of adult acute myelogenous leukemia. Oncologist 2000; 5: 454-462.

2. Steinman RA. Cell cycle regulators and hematopoiesis. Oncogene 2002; 21: 3403-3413.

3. Wang ZY. Arsenic compounds as anticancer agents. Cancer Chemother Pharmacol 2001; 48 (Suppl 1): S72-S76.

4. Rousselot P, Labaume S, Marolleau JP, Larghero J, Noguera $\mathrm{MH}$, Brouet JC, et al. Arsenic trioxide and melarsoprol induce apoptosis in plasma cell lines and in plasma cells from myeloma patients. Cancer Res 1999; 59: 1041-1048.

5. Soignet SL, Maslak P, Wang ZG, Jhanwar S, Calleja E, Dardashti LJ, et al. Complete remission after treatment of acute promyelocytic leukemia with arsenic trioxide. $N$ Engl J Med 1998; 339: 1341-1348.

6. Chiu YK, Kwan CY. Tetrandrine and related bis-benzylisoquinoline alkaloids from medicinal herbs: cardiovascular effects and mechanisms of action. Acta Pharmacol Sin 2002; 23: 1057-1068.

7. Ali BH, Al-Moundhri M, Eldin MT, Nemmar A, Al-Siyabi S, Annamalai K. Amelioration of cisplatin-induced nephrotoxicity in rats by tetramethylpyrazine, a major constituent of the Chinese herb Ligusticum wallichi. Exp Biol Med 2008; 233: 891-896.

8. Zhang Z, Wei T, Hou J, Li G, Yu S, Xin W. Tetramethylpyrazine scavenges superoxide anion and decreases nitric oxide production in human polymorphonuclear leukocytes. Life Sci
We conclude that proliferation inhibition in HL-60 cells increased after treatment with $300 \mu \mathrm{g} / \mathrm{mL}$ TMP in combination with $0.5 \mu \mathrm{M} \mathrm{As}{ }_{2} \mathrm{O}_{3}$. This increase in proliferation inhibition following combined therapy was much higher than that elicited by $\mathrm{As}_{2} \mathrm{O}_{3}$ treatment alone. Combined treatment also increased the differentiation of HL-60 cells, decreased the number of cells in the $S$ phase, increased the number of cells in the G0/G1 phase, and influenced the expression of associated cell cycle proteins. Small doses of TMP potentiated $\mathrm{As}_{2} \mathrm{O}_{3}$-induced differentiation of $\mathrm{HL}-60$ cells, possibly by regulating the expression and activity of $\mathrm{GI} / \mathrm{S}$ phase-related molecules. These results suggest that combined treatment with two chemotherapeutic agents at low concentrations can improve the cytotoxic effects on cancer cells with minimal side effects.

\section{Acknowledgments}

We thank colleagues for providing technical assistance and insightful discussions during the preparation of the manuscript. Yuni Wu studied materials, data analysis, and drafted the paper. Youhua Xu provided the concept. Yali Shen and Cuicui Wang contributed to the concept and data analysis. Gaili Guo and Tiantian Hu conducted studies on arsenic trioxide.
2003; 72: 2465-2472.

9. Yang $X G$, Jiang $C$. Ligustrazine as a salvage agent for patients with relapsed or refractory non-Hodgkin's lymphoma. Chin Med J 2010; 123: 3206-3211.

10. Fan K, Li ZM. Effect of tetramethylpyrazine on proliferation of HL-60 leukemic cells induced by vascular endothelial growth factor. J Clin Rehabilit Tissue Engin Res 2003; 72: 2472.

11. Kang HK, Suh JH, Lee JJ, Yoon SH, Hyun JW, Choi SW, et al. Induction of the differentiation of HL-60 promyelocytic leukemia cells by L-ascorbic acid. Free Radic Res 2003; 37: 773-779.

12. Freire $A C$, de Assis CF, Frick AO, da Silva MP, Haun M, Aoyama $\mathrm{H}$, et al. Influence of protein phosphatase inhibitors on HL60 cells death induction by dehydrocrotonin. Leuk Res 2003; 27: 823-829.

13. Seo BR, Lee KW, Ha J, Park HJ, Choi JW, Lee KT. Saucernetin-7 isolated from Saururus chinensis inhibits proliferation of human promyelocytic HL-60 leukemia cells via G0/G1 phase arrest and induction of differentiation. Carcinogenesis 2004; 25: 1387-1394.

14. Hintz KK, Ren J. Tetramethylpyrazine elicits disparate responses in cardiac contraction and intracellular $\mathrm{Ca}^{2+}$ transients in isolated adult rat ventricular myocytes. Vascul Pharmacol 2003; 40: 213-217.

15. Liang MJ, He LC, Yang GD. Screening, analysis and in vitro vasodilatation of effective components from Ligusticum Chuanxiong. Life Sci 2005; 78: 128-133.

16. Sheu JR, Kan YC, Hung WC, Lin CH, Yen MH. The anti- 
platelet activity of tetramethylpyrazine is mediated through activation of NO synthase. Life Sci 2000; 67: 937-947.

17. Buolamwini JK. Cell cycle molecular targets in novel anticancer drug discovery. Curr Pharm Des 2000; 6: 379-392.

18. Dimitroulakos J, Thai S, Wasfy GH, Hedley DW, Minden MD, Penn LZ. Lovastatin induces a pronounced differentiation response in acute myeloid leukemias. Leuk Lymphoma 2000; 40: 167-178.

19. Grana X, Reddy EP. Cell cycle control in mammalian cells: role of cyclins, cyclin dependent kinases (CDKs), growth suppressor genes and cyclin-dependent kinase inhibitors (CKIs). Oncogene 1995; 11: 211-219.

20. Morgan DO. Principles of CDK regulation. Nature 1995; 374 : 131-134.

21. Hunter T, Pines J. Cyclins and cancer. II: Cyclin D and CDK inhibitors come of age. Cell 1994; 79: 573-582.

22. Ponzielli R, Katz S, Barsyte-Lovejoy D, Penn LZ. Cancer therapeutics: targeting the dark side of Myc. Eur $J$ Cancer 2005; 41: 2485-2501

23. Dimberg A, Bahram F, Karlberg I, Larsson LG, Nilsson K, Oberg F. Retinoic acid-induced cell cycle arrest of human myeloid cell lines is associated with sequential downregulation of $\mathrm{c}-\mathrm{Myc}$ and cyclin $\mathrm{E}$ and posttranscriptional up-regulation of p27(Kip1). Blood 2002; 99: 2199-2206.

24. Huang MJ, Cheng YC, Liu CR, Lin S, Liu HE. A smallmolecule c-Myc inhibitor, 10058-F4, induces cell-cycle arrest, apoptosis, and myeloid differentiation of human acute myeloid leukemia. Exp Hematol 2006; 34: 1480-1489.

25. Cai X, Yu Y, Huang Y, Zhang L, Jia PM, Zhao Q, et al. Arsenic trioxide-induced mitotic arrest and apoptosis in acute promyelocytic leukemia cells. Leukemia 2003; 17: 1333-1337.

26. Antman $\mathrm{KH}$. Introduction: the history of arsenic trioxide in cancer therapy. Oncologist 2001; 6 (Suppl 2): 1-2.

27. Jakubowicz-Gil J, Paduch R, Piersiak T, Glowniak K, Gawron A, Kandefer-Szerszen M. The effect of quercetin on pro-apoptotic activity of cisplatin in HeLa cells. Biochem Pharmacol 2005; 69: 1343-1350.

28. Takeuchi H, Kondo Y, Fujiwara K, Kanzawa T, Aoki H, Mills $\mathrm{GB}$, et al. Synergistic augmentation of rapamycin-induced autophagy in malignant glioma cells by phosphatidylinositol 3-kinase/protein kinase B inhibitors. Cancer Res 2005; 65: 3336-3346

29. Izdebska M, Grzanka A, Ostrowski M, Zuryn A, Grzanka D. Effect of arsenic trioxide (Trisenox) on actin organization in K-562 erythroleukemia cells. Folia Histochem Cytobiol 2009; 47: 453-459. 